\title{
Great Basin Experiment Station Completes 60 Years
}

\section{WENDELL M. KECK ${ }^{1}$}

Director, Technical Writers' Services, Ogden, Utah.

\section{Highlight}

The Great Basin Experimental Range in central Utah completes 60 years of continuous ecological research in 1972. Scientists at this experiment station have pioneered research in watershed management, range management, climatology, and plant ecology. Great Basin Experimental Range will be the locale for the Society's summer tour for 1972.

At the distance of 60 years, one is tempted to speculate whether Dr. Arthur W. Sampson, director of the newly established Utah Experiment Station, had any idea of the farreaching significance of the work he was starting. Could he or anyone else have guessed that forthcoming experiments and studies conducted in Ephraim Canyon and on the high Wasatch Plateau would eventually lead to establishment of a science of range management? Or that rangeland would someday be recognized as a national resource with multiple values, to be protected and managed rather than taken for granted and exploited? Or that one day there would be an international professional society of men vitally interested in range preservation and improvement? Such speculation is interesting and inconclusive, but it may lead to realization of why the Forest Service and the Society for Range Management are both giving public recognition this July to the 60 years of continuous research carried on at Great Basin Experimental Range. ${ }^{2}$

\footnotetext{
${ }^{1}$ Formerly editor for the Intermountain Forest and Range Experiment Station, Ogden, Utah. All photos are by the author.

${ }^{2}$ The name "Utah Experiment Station" was changed officially to "Great Basin Experiment Station" in 1918. Since then several names have been used, but Forest Service personnel and numerous SRM members know it best as the Great Basin Station.
}

\section{Establishment}

The Station was created in 1912 by administrative decision of Forester Henry S. Graves. The site for the headquarters in Ephraim Canyon was selected in June of that year. The first buildings were a residence for the director, an officelaboratory building, a residence for assistants, and a barn. All these buildings except the assistants' residence, which burned in 1935, are in use today. Two additional residence-dormitory houses were built in 1933 as Givilian Conservation Corps projects, and other storage and service buildings have been added as needs arose.

The Station was established in response to numerous urgent requests to the Secretary of Agriculture for a study to determine causes of summertime floods that started on mountain watersheds and seriously damaged farms and rural communities in several areas of the West. These mud-rock floods had been especially severe in canyons along the Wasatch Front, and their frequency and destructiveness wcre increasing. Ephraim Canyon sustained several destructive floods between 1889 and 1910. Manti Canyon, a few miles to the south, flooded many times between 1888 and 1902; but it was closed to grazing for several years following creation of the Manti Forest Reserve in 1903 and has had no serious flood since then. Robert V. R. Reynolds' bulletin "Grazing and floods: a study of conditions in the Manti National Forest, Utah" (1911) attributed these floods to prolonged overgrazing of the mountain plateau above the heads of these canyons.

\section{Climatic Studies}

Climatic studies started early in the life of the Utah Experiment
Station, and records of temperatures and precipitation have been continued until the present. In his report of the Station's first year of work, Director Sampson wrote: "In order to propose experimental work intelligently one of the essential and initial steps is to study the conditions which control vegetation, stream flow and the like." As a preliminary to the studies of erosion on the Wasatch Plateau, measurements and records of the temperatures of air and soil and of precipitation and soil moisture were made at 10,000 feet. These records are the basis for the first major studics of climate in this particular area; they had immediate and direct bearing on erosion studies, and over the long term they were part of the important plant studies in the revegetation phase of the range program.

In 1913 Director Sampson set up meteorological stations at elevations of $7,100,8,700$, and 10,000 feet in the heart of the oakbrush, aspen-fir, and spruce-fir associations, respectively. At these stations major environmental factors (air temperature, sunshine, precipitation, evaporation, barometric pressure, and wind velocity) were recorded so that the climatic characteristics of each type-zone were well known. Records of temperature and precipitation have been continued until the present (Fig. 1).

\section{Watersheds $A$ and $B$}

Among all the numerous experimental studies at the Great Basin Station, the best known and possibly the most significant was the study of Watersheds A and B (originally called Erosion Areas). ${ }^{3}$ These two watersheds, covering 11 and 9 acres, respectively, were established in 1912 near the summit of the Wasatch Plateau. Their vegetal cover was poor, and they were in an area subject to the typical brief

\footnotetext{
${ }^{3}$ For a full account see Richard $O$. Meeuwig. 1960. Watersheds A and B-a study of surface runoff and erosion in the subalpine zone of central Utah. J. Forest. 58:556-560.
} 


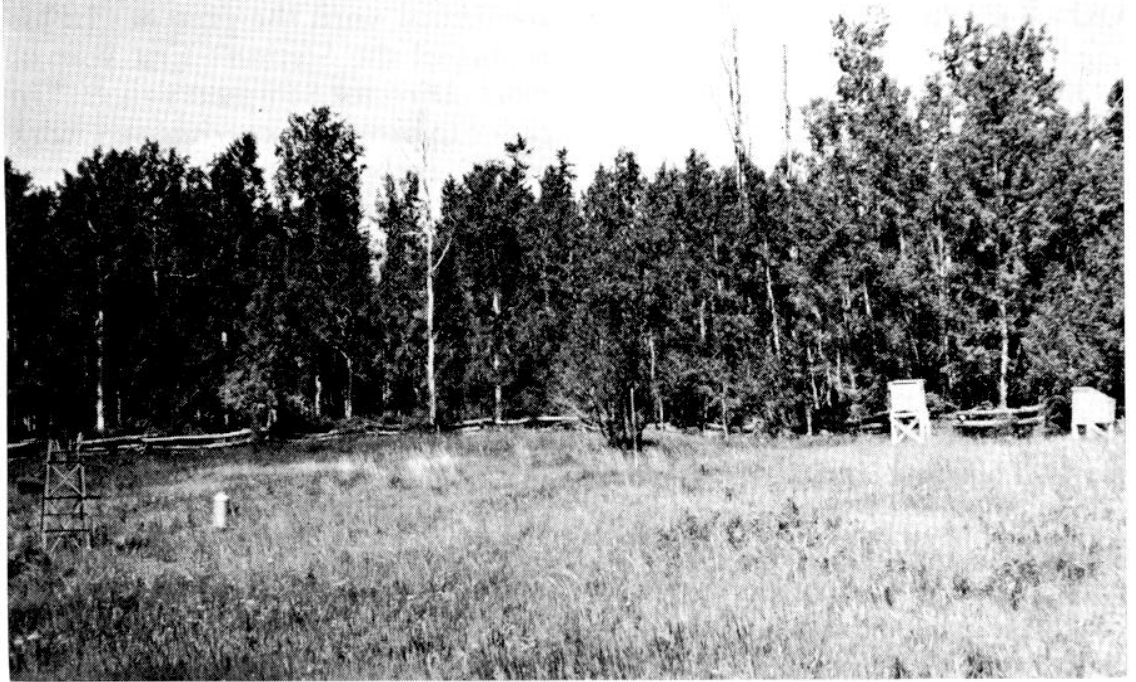

FIG. 1. A snow gauge, rain gauge, and thermometers in the old nursery area at Station headquarters keep climatic records up to date.

but intense summer storms that often produced floods. The treatments applied to these two watersheds were essentially manipulations of vegetal cover. They extended through 40 years. There has been no runoff from summer storms since 1953, and the vegetation has improved from a sparse stand of low-value herbs to a good stand of palatable grasses and forbs (Fig. 2). Erosion and sediment production on both watersheds are negligible.

The studies on Watersheds A and $B$ have shown conclusively that summer floods are a direct result of reducing plant cover below minimum amounts required to prevent excessive runoff from high-intensity summer storms. This means, in turn, that wherever vegetal cover has been severely depleted by whatever means, contour trenching and seeding probably should be used to restore satisfactory watershed conditions.

Apart from the importance of the information developed by this long-term experiment and demonstration, we must reckon other things that make this study outstanding. One is the length of continuous observation required. Another is the length of continuous climatic records available from this study -60 years' duration. Vegetation has been surveyed periodically through six decades. Surface runoff and the resulting sediment have been measured since 1915 and summer storm intensities have been recorded since 1919 . The tremendous mass of recorded data is invaluable to anyone studying the environment of the Intermountain region. But most important is the happy fact that only the oldest residents in valley towns today can remember any summer flood roaring down from the mountaintop.

The problem of summertime floods was soon demonstrated to be a problem of watershed management; and this was clearly shown to be related to faulty range management and grazing practices. As Sampson, C. L. Forsling, and their successors continued to probe the varied needs of range plants for moisture, sunshine, and nutrients, they developed growing awareness of the complexity of range. These men soon realized that mountaintop range areas suffered from two types of serious damage: valuable forage species had been killed out, and several inches of valuable topsoil had been washed or blown away. Of these, the loss of topsoil

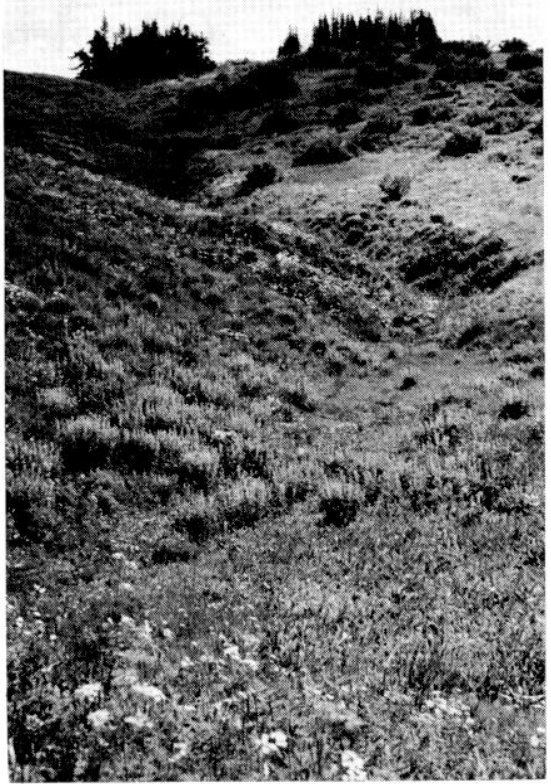

Fig. 2. In 1970 Watershed A had good cover of grass and forbs.

was the more serious, but it may not have been realized then.

\section{Plant Studies}

Need for vegetal cover on these lands was demonstrated by the treatments on Watersheds $\mathrm{A}$ and B. But how to restore plant cover to virtually bare ground, then how to maintain it, and finally how to graze these areas and still preserve soil stability and productivitythese were knotty and continuing problems, and not all the answers have been found yet. In fact, it sometimes seemed that solution of one problem brought forth a host of new ones that also required solving.

Sampson early began a series of studies of plant vigor, to learn how plants survived under various intensities of grazing. He started other experiments to determine whether overgrazed areas could reseed themselves or whether they required artificial restoration. If direct seeding were resorted to, what species were best adapted to highelevation ranges? When should they be planted? What cultural methods should be used? First attention was given to native species, 
but in recent years numerous exotic species have been tested for adaptability.

Presence of several poisonous plant species-notably tall larkspur (Delphinium barbeyi)-was always a nuisance, sometimes a plague, on western ranges. In 1919 Earl Storm reported annual losses of 6,000 cattle and 16,000 sheep within $\mathrm{Na}$ tional Forests due to eating poisonous plants. Sampson's study to determine feasible methods for eradicating larkspur showed that the growing plant stored its food chiefly in its roots and collar; hence, grubbing the plants an inch or two below the ground surface gave reasonably good control. His study provided essential background for plant food studies made 20 years later by E. C. McCarty and Raymond Price.

\section{Aspen Studies}

Aspen dominates several million acres of high-elevation summer range in the Rocky Mountain and Intermountain regions. The abundant undergrowth furnishes considerable cover and forage for wildlife and livestock, but early studies showed that grazing in this type must be carefully controlled to assure adequate reproduction of the aspen. Interest in aspen range continued, and many years later Jack Major, Walter Houston, and Lincoln Ellison resumed research on aspen. They were interested in the production of forage in openings in aspen forest as well as within the aspen stand itself.

Sampson studied aspen silviculture in his investigation of the effect of grazing upon aspen reproduction. F. S. Baker made far more elaborate studies, and his major publication on the subject, which appeared in 1925, was the first one to describe the phenology, growth, form, root systems, and the climatic, moisture, and soil requirements of the species. Baker and other early workers recognized that the aspen type is perpetuated by fire and that naturally occurring fires have enabled many sites to be

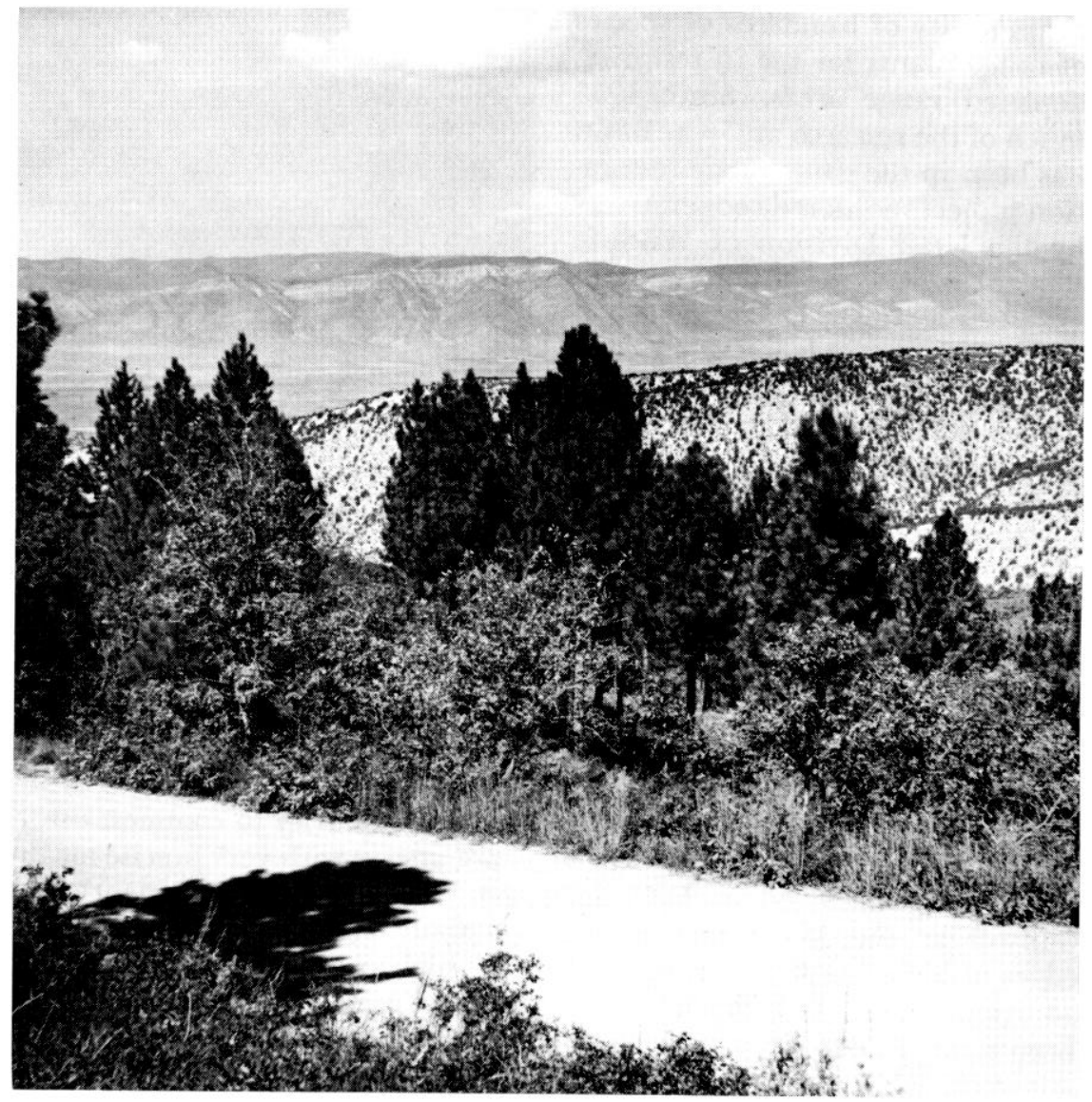

FIG. 3. Ponderosa pine trees planted by F. S. Baker in 1916 near Ephraim Canyon road.

occupied by aspen for extremely long periods. In the absence of fire, aspen is succeeded by conifers.

The only other major silvicultural project of current interest was the study by Baker and C. F. Korstian of the so-called "pineless belt" that extends from west central Montana southwesterly to the Gulf of California. This belt, several hundred miles wide in some places, is not devoid of pine, but it naturally supports virtually no ponderosa (Pinus ponderosa)-or western yellow pine, as it was formerly called. It is a brushland belt that runs through some of the usual habitat of ponderosa, and the Great Basin Station is well within the belt. Baker and Korstian carefully studied climate, soil, and other factors that might account for absence of ponderosa. Their plantations in Ephraim Canyon had counterparts on the east side of the Wasatch Plateau, and they set out scattered plantings from southern Idaho south to the Cedar City area. Many pine trees they planted in Ephraim Canyon can be seen today along the roadside (Fig. 3). They are from 30 to 50 feet high, have diameters of 8 to 10 inches, and look reasonably thrifty; but close inspection of the planted areas reveals no regeneration. Baker and Korstian concluded that deficiency of rainfall in July and August plus the generally calcareous, heavy, finegrained soils of the brushlands combined to prevent natural reproduction of ponderosa in this belt.

\section{Game Range Restoration}

Other work at the Great Basin Station over the years has included studies of climatic phenomena, the effects of rodent populations, various deferred- and rotation-grazing schemes, food storage cycles in plants, induced snowdrifting, and 
adaptability of hundreds of species of range plants for use in restoring depleted range areas. Since 1955 much of the research at Great Basin has been in the game range restoration project sponsored cooperatively by the Utah Division of Wildlife Resources and the Intermountain Forest and Range Experiment Station. This research has been complex because of the varied character of the environment. Some winter range areas in the desert receive less than 8 inches of rainfall annually whereas some mountaintop areas receive more than 60 inches. Growing seasons vary from 120 days in some valleys to only 70 days in the spruce-fir zone. Terrain varies from fairly flat to steep, and soils are derived from a variety of parent materials.

Intensive trials of forbs, shrubs, and grasses and of planting systems have been conducted in Ephraim Canyon at the lower and upper edges of big-game winter range. In addition, numerous grasses have been tested in plantings at the summit of the Wasatch Plateau (Fig. 4). Species that have shown promise of adaptability have been tested further at more than 50 outlying sites over Utah. Study of forbs and shrubs has been stressed because far less has been published about them than about grasses. This project, directed by A. Perry Plummer, has given substantial results, which have been applied in unusually short time. Successful restoration programs have already been completed on more than 120,000 acres in Utah alone. Several other landmanaging agencies in Utah and neighboring states have adopted these treatments directly or with minor local adaptations.

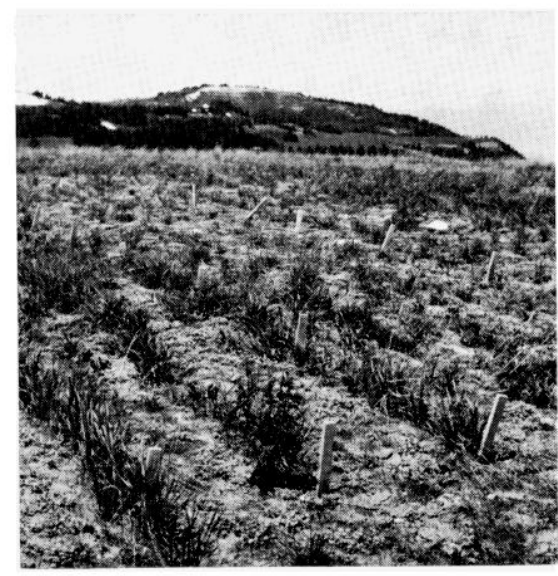

FIG. 4. Grass seeding trial area at 10,300 feet elevation on the Skyline Drive, Wasatch Plateau.

\section{Ecology and Environment}

In much less than a decade the word "ecology" has emerged from relative obscurity to common usage -not always with very precise meaning. Likewise, "environment" has suddenly achieved popularity and well-nigh universal usage. Many persons seem to believe that both these terms and the research they refer to are as new as their current widespread usage. But environmental and ecological studies have been progressing for 60 years at the Great Basin Station. Research pioneered and carried out there has touched every aspect of range management including the development of the science itself. Indeed, the term "range science" is heard today with increasing frequency. The early plant studies developed into rather elaborate investigations of fundamental plant behavior that greatly extended the scope of early ecological knowledge.

What happened in the development of range management was rather closely paralleled by studies of watersheds and their management. The studies on Watersheds $\mathrm{A}$ and $\mathrm{B}$ established the necessity for having certain minimal vegetal cover on high-elevation watershed to prevent flooding after brief, intense summer storms. Principles derived from the experiments on the Wasatch Plateau were demonstrated effectively by Reed W. Bailey and others in treatment of the Davis County watersheds after disastrous mud-rock floods in the 1930's.

Continuing ecological studies at the Great Basin Station have had important use in National Forest administration-in determining grazing capacity of allotments, in deciding when grazing on forest lands may safely start in spring and summer, and when it must be stopped in autumn. Much of the research at Great Basin could be classified appropriately as "basic" or "fundamental," but every study has been oriented to practical use.

From the foregoing account it should be apparent why the Forest Service and the Society for Range Management are combining efforts to celebrate 60 years of progressive service at the Great Basin Station headquarters late in July. At that time the Forest Service will officially open a self-guiding conservation tour of designated stops along the Ephraim Canyon road. A plaque honoring Dr. Sampson will be unveiled near the office-laboratory he built in 1913. Ephraim Canyon will be the locale for the SRM Summer Tour for 1972. Participating members are assured a scenic and informational treat as they are conducted through this historically rich area in central Utah.

\section{Specialists in Quality NATIVE GRASSES}

Wheatgrasses • Bluestems • Gramas • Switchgrasses • Lovegrasses • Buffalo • and Many Others

We grow, harvest, process these seeds

Your Inquiries

Appreciated

SHARP BROS. SEED CO.

Phone 398-2231

HEALY, KANSAS 